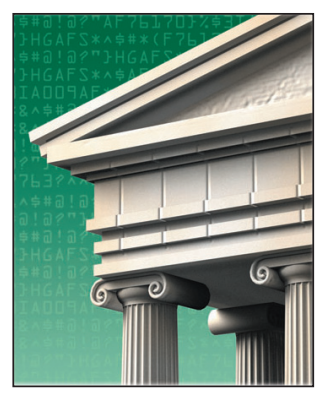

ICT R\&D Policies

\title{
An International Perspective
}

Stephen Ezell and Scott Andes • Information Technology and Innovation Foundation

Information and communication technology (ICT) is a crucial driver of economic growth. This has made ICT R\&D vital to sustaining ICT as an engine of global growth. Although the US still performs the most ICT R\&D globally, competition has intensified as US ICT R\&D investment as a percentage of GDP has fallen noticeably - and has been surpassed by competitors - in the past decade.

I nformation and communication technology (ICT) is a crucial driver behind innovations in Internet computing and drives economic growth and citizens' quality of life. ${ }^{1,2}$ In fact, ICT has accounted for 25 percent of US economic growth since 1995, despite constituting just 3 percent of US GDP (www.nap.edu/catalog. php?record_id=12174). Sustaining the breakneck pace of innovation in ICT requires high levels of REtD. Indeed, in terms of RAD expenditures, patents, and venture capital investments, the ICT sector exceeds all other industries by a large margin (www.oecd.org/sti/ito). For firms in ICT and non-ICT industries alike, ICT R\&D drives a robust pipeline of next-generation products and services. For example, US government-funded ICT RED led to development of the Arpanet - the precursor to the commercial Internet and subsequent private sector ICT RED into the Ethernet and wide-area networks led to development of companies such as Cisco and 3Com. Continued Internet-related ICT R\&D contributed to development of the Mosaic Web browser, Web search algorithms, and enhanced Internet security protocols. For nations, maintaining high levels of ICT R\&D sustains the health of their domestic ICT firms and ecosystems, contributes to development of new technologies and even entirely new industries, and supports the creation of numerous high-paying jobs.

Here, we examine ICT R\&D's critical importance to economic growth, compare countries' levels and rates of change in ICT R\&D inten- sity (investment as a percentage of GDP), assess governments' levels of ICT RED funding, and analyze several policy issues pertaining to ICT RED. We've found that, although the US clearly leads the world in aggregate ICT R\&D investment, international competition for ICT RED leadership has increased substantially, with nations such as Korea and Finland investing a greater percentage of their GDP than the US. This has led to US ICT RED intensity falling considerably relative to its peers during the past decade. We've also found that China and India have significantly increased their levels of ICT RED investment and that China has the world's second fastest growth rate in business RAD expenditures.

\section{Economic Growth}

ICT achieves its outsized economic impact by affecting the economy via two channels: directly, through the ICT sector itself, and indirectly, through other sectors that are powered by ICT advances. To get a sense for ICT's direct contribution to economic growth, consider that, since 1980, fundamental research into ICT has given rise to almost 20 entirely new ICT-related product categories that have become multibillion dollar industries. These include OSs, client-server computing, the Internet, GUIs, the World Wide Web, and broadband infrastructure, to name a few (www.nap.edu/catalog. php?record_id=12174). The European Information Technology Observatory estimated that 


\section{Further Reading}

the global ICT market itself totaled US\$3.1 trillion in July 2008, growing at 5.3 percent annually (www. eito.com/reposi/FreeDataSheets/ ICT-MarketOverview-world).

Furthermore, ICT makes indirect contributions to economic growth by enhancing worker and organizational productivity, so much so that ICT has accounted for more than half of US productivity growth over the past 15 years. Scholars note that, although most ICT-related productivity gains in the late 1990s came from ICT-producing industries, the 2000s were marked by a sharp rise in productivity growth in ICT-using industries, especially services and trade industries, because ICT contributed to the rise of more efficient "digital organizations." 3,4 Productivity studies reveal that ICT contributed substantially to the 2.6 percent productivity growth rate realized from 2007 to 2008 and that firms that both make ICT investments and adopt productivity-enhancing business practices generally outperform their peers in productivity, profitability, and market valuation. ${ }^{3,4}$

At the macroeconomic level, the Information Technology and Innovation Foundation (ITIF) has estimated that the annual global economic benefits from commercial Internet-enabled efficiencies alone will equal US\$1.5 trillion in 2010 (www. itif.org/files/2010-25-years.pdf). (E-commerce delivers 15 percent savings over other forms of commerce; taking 15 percent of the $\$ 10$ trillion e-commerce market means the global economy is $\$ 1.5$ trillion larger than it otherwise would be in the absence of e-commerce.) Yet, this figure represents only the value of the Internet economy. The ITIF estimates that ICT, in general, has made the US economy approximately $\$ 2$ trillion larger in terms of annual GDP than it would be otherwise (www.itif.org/files/2010-25-years. pdf). ICT also represents a substan-

$T$ he Organization for Economic Cooperation and Development's (OECD's) "Information Technology Outlook 2008" (www.oecd.org/sti/ito) provides a comprehensive assessment of OECD countries' ICT R\&D investments. The OECD's "Science, Technology, and Industry Scoreboard 2009" (www.oecdilibrary.org/ content/book/sti_scoreboard-2009-en) updates many R\&D indicators, such as R\&D tax credit levels and government R\&D budgets, though not ICT R\&D data. The "2009 Report on R\&D in ICT in the European Union" (http://ftp.jrc.es/EURdoc/ JRC4995I.pdf) analyzes EU ICT R\&D investments, using the 2005 OECD data set. The National Academies' 2009 report, "Assessing the Impacts of Changes in the Information Technology R\&D System" (www.nap.edu/catalog.php?record_id=12174), examines changing trends in US ICT R\&D and global competitiveness therein.

tial source of job growth. Between 1999 and 2008, the US economy created 688,000 new ICT jobs - an increase of 26 percent - meaning that US ICT employment grew four times faster than US employment as a whole during that time frame (www.itif.org/files/2010-wm-it-jobs. pdf). Moreover, whereas the average US worker earned $\$ 42,263$ in 2008, ICT workers earned an average of $\$ 74,500$ - 75 percent greater than the average.

Thus, ICT RED is indispensible to sustaining ICT as the driver of global economic growth. Internationally, ICT RED priorities appear to be focused on eight core topic areas:

- physical computing foundations (for example, quantum computing),

- computing systems and architectures,

- converging technologies and scientific disciplines (for example, the intersection of ICT, biology, nanotechnology, and so on),

- network infrastructures,

- software engineering and data management,

- digital content technologies,

- human-technology interfaces, and

- ICT and Internet security. ${ }^{5}$

Most countries also have ICT RED efforts focusing on ICT's impact on key application areas, such as healthcare, energy, education, and transportation. In this regard, ICT R\&D is cru- cial to meeting many of the so-called "Grand Challenges" of the 21st century, such as developing novel drugs or gene therapies, modeling climate change, or exploiting the behaviors of atoms to enable nanotechnology (www.nap.edu/catalog.php?record _id=12174). ICT is also an increasingly valuable tool in many research fields, such as cloud computing in genomic research or virtual simulations to conceptualize and test new products.

\section{Expenditures by Country}

The Organization for Economic Cooperation and Development's (OECD's) "Information Technology Outlook 2008" provides perhaps the best source of internationally comparable data on ICT industry RED expenditures (www.oecd.org/sti/ito). It finds that such expenditures in the US totaled $\$ 59.6$ billion in 2005 , compared to $\$ 34.6$ billion in the EU-15, $\$ 31.6$ billion in Japan, and $\$ 16.1$ billion in Korea. A 2007 report commissioned by the French Ministry for Education, Higher Education, and Research estimated that 2005 ICT RED expenditures were $\$ 38.7$ billion in China, $\$ 10.7$ billion in India, and $\$ 7.3$ billion in Brazil, placing China second in the world. ${ }^{6}$ India's ICT R\&D expenditures were also larger than those of any single European country. In fact, total US investment in 2005 was 75 percent larger than the EU-15's (despite the comparable size of their populations) and nearly 
twice as large as Japan's. However, these expenditures are growing at a faster rate in the EU-15, Japan, and Korea. From 1996 to 2005, US expenditures grew just 6 percent, whereas ICT industry RED grew 37 percent in the EU-15, 41 percent in Japan, and 71 percent in Korea. Overall, Chinese business R\&D grew at a 22 percent average annual growth rate from 1997 to 2007, although specific ICT R\&D numbers aren't available (www. oecdilibrary.org/content/book/ sti_scoreboard-2009-en).

In 2005, 25 percent of all business REtD expenditures in the US and 18 percent in the EU were ICT-related. The share of ICT REtD conducted by non-ICT industries is also high, accounting for roughly a quarter of total ICT R\&D activity. The "2009 Report on RED in ICT in the European Union," also using 2005 data, combined ICT RED performed by both ICT and non-ICT industries, finding total US and EU ICT RED to equal $\$ 75.6$ billion and \$39.6 billion, respectively (http://ftp.jrc.es/EURdoc/JRC4 9951.pdf).

\section{Country Intensity}

Although the US accounts for the largest total share of ICT R\&D among OECD countries, when evaluating RED intensity (RED expenditures as a percent of GDP), the US ranks below several OECD countries. The US ranks 5th behind Finland, Korea, Japan and Sweden in R\&D in ICT manufacturing industries and ranks 6th for RED in ICT services industries (such as software, Internet security, or Webbased applications) behind Denmark, Finland, Ireland, Sweden, and the UK, respectively. At first glance, the US appears to score fairly well, but the data reveal a striking decrease of almost 50 percent in the amount of US ICT manufacturing industry REtD intensity from 1997 to 2005. When we combine the change in both ICT manufacturing and ICT services R\&D intensity from 1997 to 2005, the US ranks dead last in terms of progress among 21 OECD nations. Indeed, whereas Denmark, Finland, and Korea all increased their RetD intensity by more than 50 percent, the US declined by 37 percent. Some contend that the decline in ICT manufacturing RED is more than compensated for by the increased investment in ICT services REtD. But although US ICT services RED intensity did rise 20 percent from 1997 to 2005, this placed the US just 15th of 21 countries in rate of increase in ICT services R\&D. For detailed information on country ICT R\&D intensity, see the Web extra at www.computer.org/cms/ Computer.org/dl/mags/ic/2010/04/ extras/mic2010040076s.pdf.

\section{Government Support}

Publicly funded research has contributed directly to the development of many crucial ICTs, including transistors and semiconductors, the Internet, the GUI, the GPS, and Google's Web search algorithm. ${ }^{7}$ Recognizing ICT's importance to economic competitiveness, many governments fund ICT RED programs. Unfortunately, as the OECD notes, "In spite of the importance of publicly funded research for the ICT sector, internationally comparable official figures on publicly funded ICT-related RED are not available," except for the largest economies (www.oecd.org/sti/ito).

Historically, despite its strength in defense-related ICT REtD, the US has lagged behind Europe and Japan in government funding for civilian ICT REDD. As a comprehensive 2009 report from the US National Academies noted, "concerns over the level of federal support for ICT R\&D are longstanding” and funding doesn't appear to be commensurate with "the enormous and increasing importance of the field, the continued potential for high-impact breakthroughs, and the nation's investment in other fields" (www.nap.edu/catalog. php?record_id=12174). Indeed, the US's public investment in civilian ICT REtD lagged competitors - not just as a percentage of the economy, but even in absolute dollar terms from 1999 to 2005, the latter a year in which the EU-15, Japan, and the US invested US $\$ 3.5$ billion, $\$ 2.7$ billion, and $\$ 1.8$ billion, respectively. As a percentage of GDP in 2005, government funding of ICT RED in Japan, through its Information Technology Promotion Agency, was six times greater than the US and more than twice as great as the EU.

To close this gap, Congress increased funding for the US Networking and Information Technology Research and Development (NITRD) program and its 13 member agencies to more than $\$ 3$ billion in 2008, and President Obama's FY2010 budget requested $\$ 3.9$ billion for the agency. ${ }^{8}$ Legislation to reauthorize the America Competes Act (which passed on the House Floor on Friday, May 28 and now goes to the Senate for consideration) includes the Networking and Research Development Act of 2010, which calls for NITRD to develop a five-year strategic plan focusing on how ICT can support large-scale research in areas of national importance, such as the previously mentioned Grand Challenges, and specifically in Internet security, human-computer interfaces, and cyber-physical systems, such as sensors, actuators, and other control technologies. ${ }^{9}$ This funding increase and charter for NITRD is necessary to keep pace with other governments' investments to support ICT RED in their countries. For example, Europe's 7th Framework program will increase the EU's annual level of ICT R\&D funding by 50 percent between 2010 and 2013, investing more than $\$ 7$ billion during that time frame (atop additional EU investments, such as Germany's $\$ 520$ million annual investment in its ICT 2020 - Research for Inno- 
vation program and Finland's $\$ 110$ million annual funding). As noted in a US report, these commitments "are indicative of the priority, organizational effort, and resources that the EU is devoting to mounting a multiyear challenge to America's global leadership in ICT." 10 The EU knows its businesses have underinvested relative to the US and is making concerted efforts to close this gap. Japan's 2009 Science and Technology budget calls for government investment of $\$ 1.7$ billion, although it includes additional funding for ICT applications such as intelligent transportation systems. ${ }^{11}$ China's government will provide at least \$345 million annually in civilian ICT R\&D funding as part of the "Medium- and Long-term Plan for Science and Technology Development," and India's government will provide at least $\$ 130$ million annually as part of India's "Eleventh 5-Year Plan," spanning 2007 to 2012 .

\section{Action Agenda}

In addition to direct public funding for ICT REtD, extending tax credits to businesses is perhaps the most effective way governments can encourage R\&D. Research shows that, in the US, every federal dollar spent on such tax credits spur $\$ 1$ to $\$ 2$ of business RED (www.itif.org/files/2009-stim -novation.pdf). Moreover, R\&D's rate of return to society is four times that to businesses because, due to spillover effects, businesses are unable to capture all the benefits of their own investment. Robust tax credits are especially important in countering economic recessions, as businesses tend to cut REtD during downturns. For example, in June 2009, OECDarea ICT manufacturing and services REtD had declined by 11 percent overall compared to June 2008 (www. oecdilibrary.org/content/book/sti _scoreboard-2009-en). Thus, R\&D tax credits are effective policy instru-

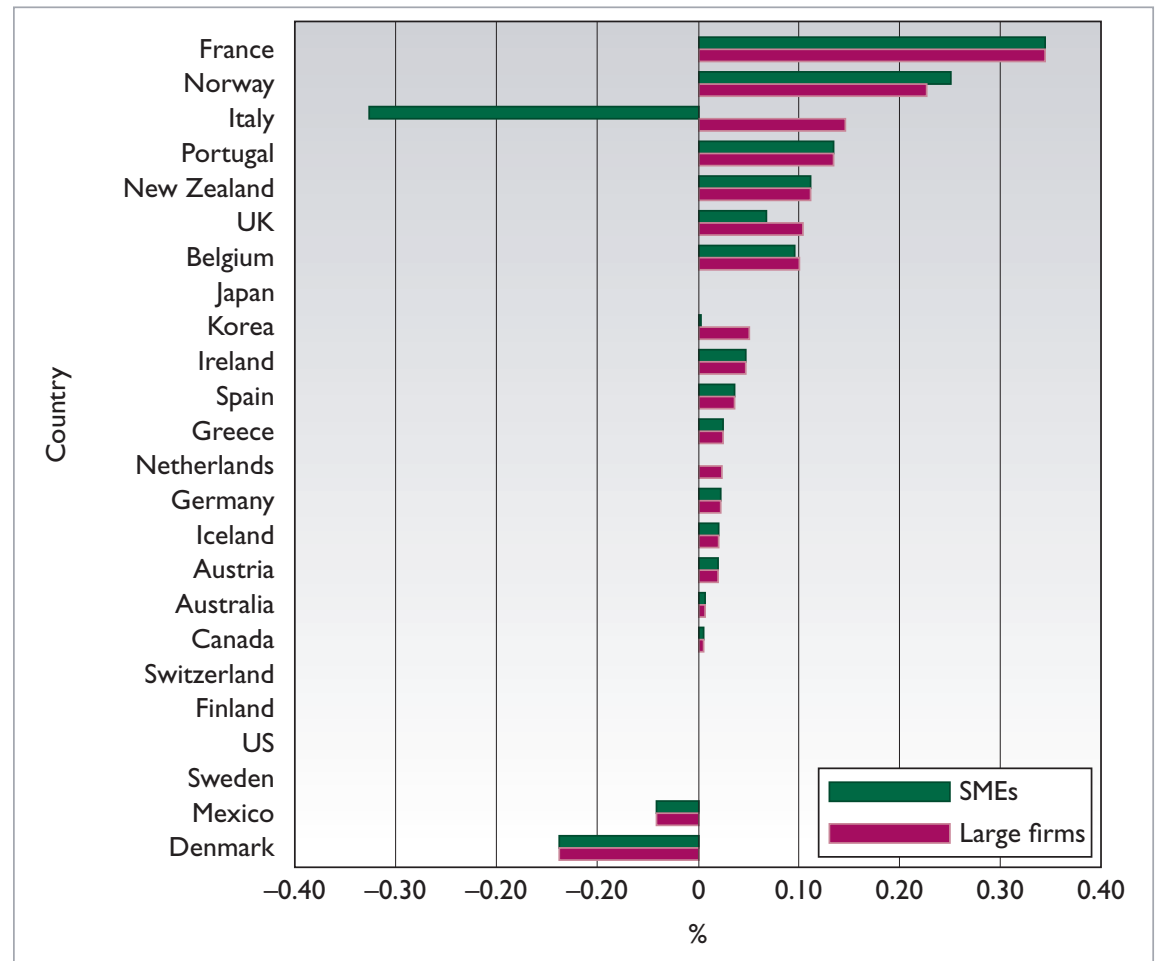

Figure I. Change in tax credit rate. The graph examines the rate change for US\$I of R\&D for small and medium-sized enterprises (SMEs) and large firms, between 1999 and 2008 (www.oecdilibrary.org/content/book/ sti_scoreboard-2009-en).

ments to encourage private-sector R\&D activity, and become even more so during economic downturns.

In 1981, the US was the first country in the world to offer an RED tax credit to businesses, long the world's most generous. But, as other countries introduced their own packages, US R\&D tax credit generosity began to wane, then fell precipitously, dropping to seventh in tax credit generosity among the 30 OECD nations by 1996 and 17th by 2004. The 2008 OECD data shows US R\&D tax credit generosity fell further still to 24th of 38 countries assessed, now behind even India, Brazil, and China. Figure 1 shows that the US is 21 st of 24 OECD countries examined in tax credit generosity rate of change between 1999 and 2008. France's R\&D tax credit is now six times more generous than the US's (www.oecdilibrary.org/content/ book/sti_scoreboard-2009-en).

To enhance this tax credit as an incentive to spur business RED, Congress should both make the tax credit native Simplified Credit rate from 14 percent to 20 percent (www.itif. org/files/2010-restoring-innovation -leadership-testimony.pdf). Congress should also introduce a 40 percent collaborative R\&D tax credit, which would encourage RED investments performed collaboratively by industry-university consortia. Congress should further broaden the definition of qualified REtD from beyond that involved in inventing a new product to include that involved in developing a new production process, as several countries have done (www.itif.org/ files/090723_CorpTax.pdf). Addressing problems with the US patent system - including a lengthy backlog of patent applications due to inadequate resources at the US Patent and Trademark Office and the issuance of too many questionable patents - would also encourage greater investment permanent and increase the Alter- 
(www.itif.org/files/PatentsPending. pdf). Implementing the Patent Reform Act of 2010, introduced in the US Senate in March, would be a much needed first step toward improving the US patent system.

CTs have revolutionized the global economy in recent decades, leading to increased productivity and higher standards of living. The economies that accrue the greatest to aggressively support ICT R\&D to keep their firms and industries at the cutting edge of innovation and application. Although the US's ecosystem was once the envy of the world in the mid-1990s, that leadership position is now at risk and can no longer be taken for granted. Maintaining benefits will be those that continue
US ICT REtD leadership in the face of heightened global competition will require proactive policy action. [G]

\section{References}

1. R. Atkinson and A. McKay, "Digital Prosperity," Information Technology and Innovation Foundation, Mar. 2007; www. itif.org/files/digital_prosperity.pdf.

2. R. Atkinson and D. Castro, "Digital Quality of Life," Information Technology and Innovation Foundation, 0ct. 2008; www. itif.org/files/DQOL.pdf.

3. E. Brynjolfsson and A. Saunders, Wired for Innovation: How Information Technology is Reshaping the Economy, MIT Press, 2010.

4. D.W. Jorgenson et al., "Industry Origins of the American Productivity Resurgence," Economic Systems Research, vol. 19, no. 3, 2007, pp. 229-252.

5. G. Vickery and S. Wunsch-Vincent, "RetD and Innovation in the ICT Sector: Toward
Globalization and Collaboration," 2009; www.tubisad.org.tr/Tr/Library/Analizler/ Toward Globalization and Collaboration.pdf.

6. "Research and Development in Information and Communication Technologies in the Major Industrial Countries," French Assoc. Electronic Information Industry, Feb. 2007.

7. R. Atkinson, The Past and Future of America's Economy: Long Waves of Innovation that Power Cycles of Growth, Edward Elgar, 2004.

8. "Supplement to the President's Budget for Fiscal Year 2010," Networking and Information Technology Research and Development Program, Feb. 2010; www.nitrd.gov/ About/FY11NITRDSupp-FINAL-Web.pdf.

9. "Mark up of America Competes Act," House Committee on Science and Technology, Apr. 2010; http://democrats.science. house.gov/Media/file/Commdocs/mark ups/2010/Full/28apr/Amendment_in_the _Nature_of_a_Substitute.pdf.

10. "Leadership under Challenge: Information Technology RaD in a Competitive World," Executive Office of the President, President's Council of Advisors on Science and Technology, Aug. 2007, p. 13.

\section{Free Sample Issues! A $\$ 26$ value}

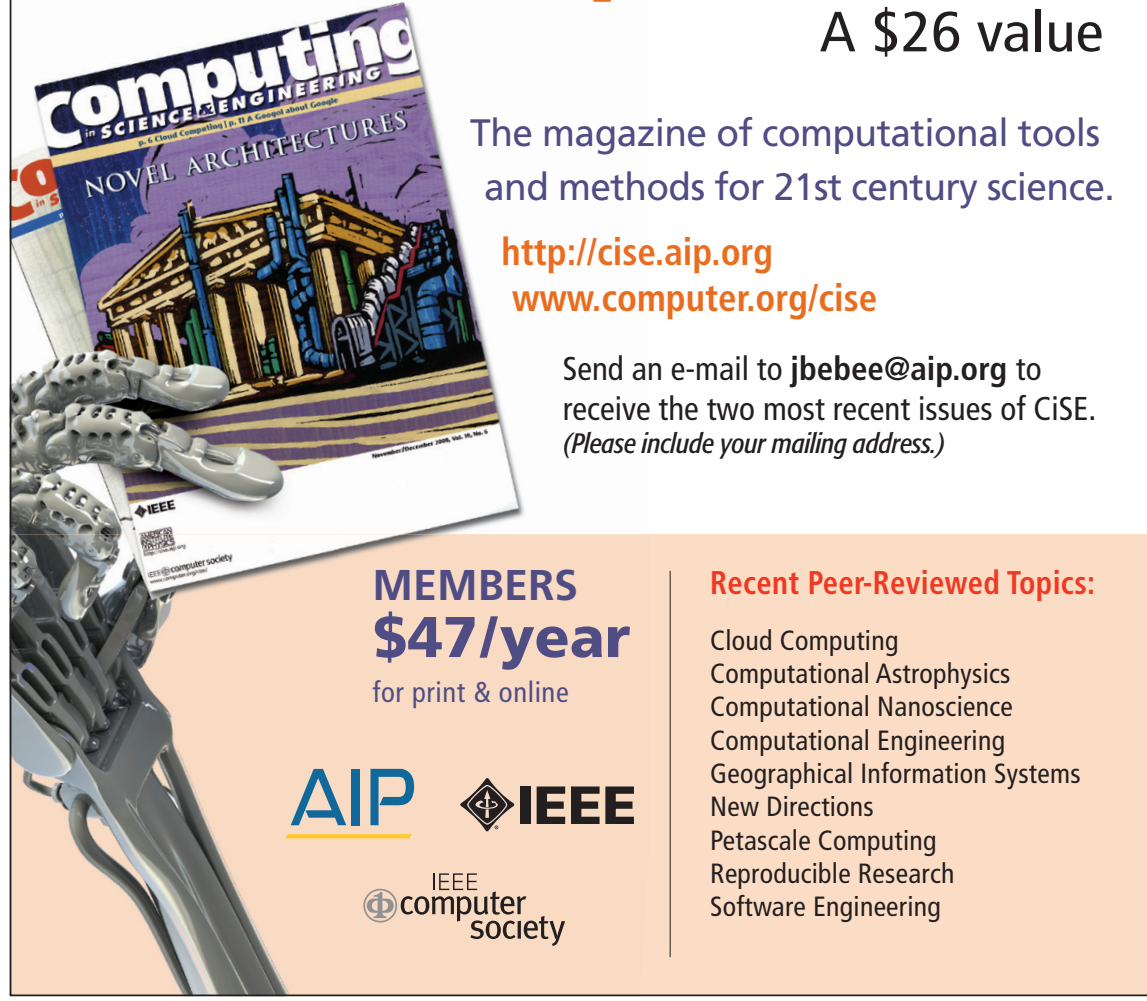

11. M. Aizawa, "FY 2009 Science and Technology Budget Priorities," Council for Science and Technology Policy, 2009; http://www.polar.se/forskarsidor/pdf/ japan/Japan\%20FY\%202009\%20Science \%20and\%20Technology\%20budget\%20 allocation.pdf.

Stephen Ezell is a senior analyst at the Information Technology and Innovation Foundation. His research interests include innovation policy, international competitiveness, and emerging information technology research. Contact him at sezell@itif.org.

Scott Andes is a research analyst at the Information Technology and Innovation Foundation. His research interests include international competitiveness, economic development, and innovation. Contact him at sandes@itif.org.

Selected CS articles and columns are also available for free at http:// ComputingNow.computer.org. 